\title{
VRIEND V. ALBERTA, LAW V. CANADA, ONTARIO V. M. aND H.: THE LATEST Steps ON the Winding Path to Substantive Equality
}

\author{
Craig D. Bavis
}

This article traces the continuing development of the analytical framework used by the Supreme Court of Canada to evaluate infringements of equality rights challenged under s. $15(1)$ of the Charter. This is achieved through examining the Court's recent decisions in Vriend, Law, and M. v. $\mathrm{H}$. in the context of the claims heard in Andrews, the 'equality trilogy' of Miron, Egan, and Thibaudeau, and the subsequent equality cases heard by the Court. This article follows the initial analytical framework introduced in Andrews. through the Court's split in 1995. It then examines subsequent cases, finding that Vriend stands as a significant case in the evolution, and that the Court's restatement of its method in Law demonstrates a renewal of the Court's unanimous commitment to substantive equality as first articulated in Andrews and indicates that the troubling position favoured by a minority of judges in 1995 has been abandoned. In examining the application of the Law analysis in M. v. H., this article recognizes the possibility that the approach may be too subjective and warns that undue focus on legislative purpose instead of effect may undermine substantive equality.
L'auteur retrace lëvolution du cadre d'analyse que la Cour suprême du Canada a utilisé pour évaluer la violation des droits à l'ëgalité aux termes du par. 15(I) de la Charte. II examine en premier lieu les arrêts Vricnd, Law et M. c. H. à la lumiere de la " trilogie "Thibaudeau. Miron et Egan, et des causes qui ont suivi. Il étudie l'analyse initiale adoptée dans Andrews et jusquä la décision avec avis minoritaire de 1995; il note que Vriend marque une étape décisive, que la reformulation de la méthode de la Cour dans Law témoigne de la volonté unanime des juges de faire respecter lëgalité véritable, comme ils l'avaient déjà signifié dans Andrews; et que la position utilisée par une minorité de juges en 1995 a été abandonnée. Au terme d'un examen de la méthode adoptée dans Law et appliquee dans M. c. H.. lauteur reconnait que l'approche pourrait eitre trop subjective et craint que la part trop grande faite à l'objet plutot qu'aux effets de la loi ne mise au principe d'égalisé vérilable.

\section{TABLE OF CONTENTS}

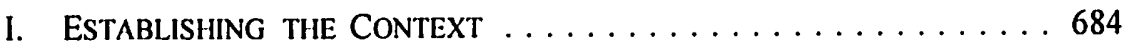

A. VRIEND, LAW AND $M$. v. H.: THE BACKGROUND ....... 685

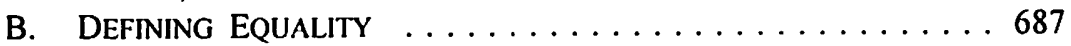

II. Creating the Analytical Framework: ANDREWS . . . . . 688

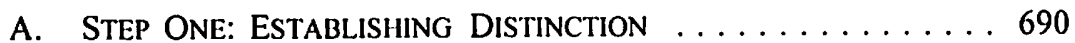

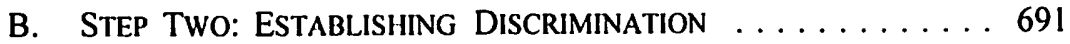

C. Section One Justification $\ldots \ldots \ldots \ldots \ldots \ldots \ldots \ldots 6.692$

III. THE POST ANDREWS PERIOD . . . . . . . . . . . . . . . 693

IV. RETHINKING THE ANALYTICAL FRAMEWORK:

THE EquAlity TRILOGY of $1995 \ldots \ldots \ldots \ldots \ldots \ldots \ldots .694$

A. MODIFYing THE FRAMEWORK: LAMER, LA FOREST,

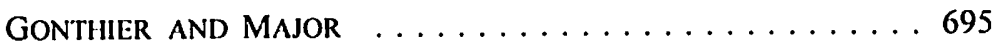

B. Maintaining the FrAMEWORK: MCLACHLIN, IACOBUCCI, CORY AND SOPINKA $\ldots \ldots \ldots \ldots \ldots \ldots \ldots \ldots \ldots$ 


\section{EXPANDING THE SCOPE OF THE FRAMEWORK:}

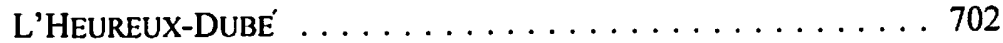

V. Downplaying Difference: The Post Trilogy Decisions . . . 703

A. ADLER V. ONTARIO . . . . . . . . . . . . . . . . . 704

B. COOPER V. CANADA (HUMAN RIGHTS COMMISSION) ...... 704

C. EATON v. BRANT COUNTY BOARD OF EDUCATION ........ 705

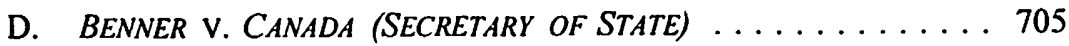

E. ELDRIDGE v. BRITISH COLUMBIA (ATTORNEY GENERAL) ..... 706

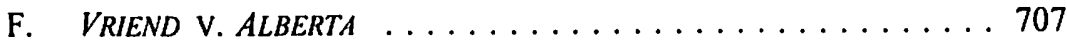

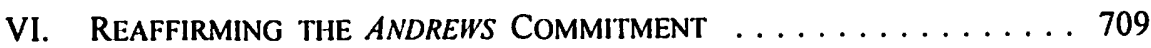

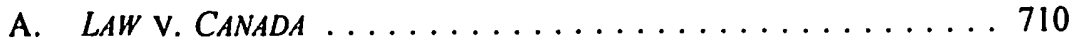

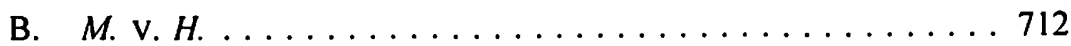

\section{ESTABLishing THE CONTEXT}

The role of the Supreme Court of Canada in recognizing and defining the social rights and responsibilities of Canadians has never been greater than in the last fifteen years. Neither has the criticism that has been levelled against the Court. The highly politicized nature of equality rights ensures that any decision that the Court makes on a contentious issue will win it simultaneous commendation and condemnation, as the public reaction to the recent rulings in Vriend v. Alberta ${ }^{1}$ and Ontario v. $M$. and $H^{2}{ }^{2}$ illustrates. The Court's decision in Vriend to read sexual orientation into Alberta's human rights legislation as a prohibited ground of discrimination against the express wish of the Alberta Legislature has been praised by gay and lesbian rights activists as rectifying a fundamental injustice and at the same time scorned by others as an undemocratic and inappropriate intrusion into the legislative domain of elected government representatives.

While both these aspects of the Vriend decision are interesting and relevant issues, this decision of the Court has an additional and equally important dimension. Examining Vriend in the context of the Court's approach to adjudicating equality rights illustrates the greater significance of this case beyond the issues it directly addresses. The decision provides an opportunity to examine how the analytical framework used in equality cases of the Court operates, the different ways it has been applied over the last nine years, and the changing views of members of the Court. Understanding Vriend in this context plays an important role in understanding the need for the Court's restatement of its s. 15(1) analysis in Law v. Canada ${ }^{3}$ and provides insight into the Court's application of that analysis in $M$. v. $H$.

Delwin Vriend and Gala-Gay and Lesbian Awareness Society of Edmonton. Gay and Lesbian Community Centre of Edmonton Society, and Dignity Canada Dignité for Gay Catholics and Supporters v. Alberta (A.G.), [1998] I S.C.R. 493 [hereinafter Vriend].

2 Ontario (A.G.) v. $M$. and $H$. (Indexed as $M$. v. $H$.) Supreme Court of Canada File No. 25838, Judgment delivered 20 May 1999 [hereinafter $M$. v. H.].

Law v. Canada (Minister of Employment and Immigration) Supreme Court of Canada File No. 25374, Judgment delivered 25 March 1999 [hereinafter Law]. 


\section{A. VRIEND, LAW AND $M$. V. H.: The BACKGRound}

Delwin Vriend worked as a laboratory co-ordinator at King's College, a Christian school in Edmonton, Alberta, from 1987 until his employment was arbitrarily terminated in January 1991. The College had recently adopted a policy against employing homosexuals in order to recognize one of the fundamental beliefs of the religious College: homosexuality is morally wrong. Vriend lodged a complaint with the Alberta Human Rights Commission. The Commission, however, refused to investigate on the ground that sexual orientation is not a prohibited ground of discrimination under the Individual Rights Protection Act, ${ }^{4}$ Alberta's human rights legislation. In 1992, Vriend sought and obtained a declaration from the Court of Queen's Bench of Alberta that the IRPA violated s. 15(1) of the Canadian Charter of Rights and Freedoms because the IRPA failed to include sexual orientation as a prohibited ground of discrimination.

Vriend's victory was short lived, as the Government of Alberta appealed Russell J.'s remedy of reading in sexual orientation to the provisions of IRPA. In 1996, a majority of the Court of Appeal, consisting of McClung and O'Leary JJ.A. with Hunt J.A. dissenting, allowed the appeal. The appellate court ruled that the Charter does not apply to legislative silence, only government action, and that the failure to include sexual orientation in the IRPA did not violate s. 15(1) of the Charter, and, as such, Vriend had not been discriminated against. Vriend appealed this decision to the Supreme Court of Canada. In April 1998, the Court found unanimously for Vriend and read sexual orientation into the IRPA. This result was far from certain and prior to the hearing of the case there was a real question as to which way the Court would decide, in light of the Court's split on equality rights analysis in 1995.

Ironically, had the Supreme Court heard Vriend's case at the time that he was terminated in 1991, he would have been much more sure of a favourable result than he was in 1997. In 1989 the Supreme Court made its first decision on a s. 15(1) claim, Andrews v. The Law Society of British Columbia. ${ }^{5}$ In that judgment the Court adopted a substantive interpretation of equality that many heralded as the dawning of a new era of social progressiveness and as a demonstration of the Court's commitment to achieving substantive equality. In the years following that decision, however, three cases were decided that would seem to temper that belief as the unanimity of the Court evaporated in 1995, resulting in several different approaches to equality analysis. At that time, some members of the Court appeared to have retreated from the position that the Court first espoused in Andrews.

Interestingly, in the judgments released after the split in the 1995 cases, it appears that the minority of the Court that had adopted a more restrictive method of equality analysis has rethought its position. These judgments of the Court strive to downplay the difference between the divergent approaches, and the latest judgments, Vriend, Law and

$4 \quad$ R.S.A 1980, c. I-2, as am. by Human Rights, Citizenship and Multiculturalism Act, R.S.A. 1980, C. H-11.7 [hereinafter IRPA].

s [1989] I S.C.R. 143 [hereinafter Andrews]. 
$M$. v. $H$., make no reference at all to the minority position that so troubled many in 1995. Whether this trend to downplay the divergence of the Court would hold in Vriend was a seriously debated issue as the underlying issue, the acceptance of homosexuality, was a much more contentious issue than any in the cases heard during the previous two years. The unanimous judgment in favour of Vriend was evidence of the continuing trend to downplay difference and promote consensus amongst the Court.

In March 1999, shortly after the tenth anniversary of the Court's decision in Andrews, the Court took the opportunity that arose in Law v. Canada to unanimously restate its approach to s. 15(1). In 1992, the appellant, Nancy Law, had challenged the provisions of the Canada Pension Plan ${ }^{6}$ that denied her survivor benefits because she was an able-bodied surviving spouse without children under the age of thirty. Law appealed on the grounds that the plan discriminated on the basis of age, contrary to the Charter. Law's appeal to the Minister of National Health and Welfare was rejected, as was her appeal to the Pension Plan Review Tribunal, which found a violation of $\mathrm{s}$. 15(1), that was justified under s. 1 of the Charter. Law's appeal of this ruling to the Pension Appeal Board and the subsequent appeal to the Federal Court of Appeal were unsuccessful as both found no violation of s. 15(1). The Supreme Court of Canada restated its approach to s. 15(1) claims and stressed the need for a purposive and contextual approach that recognized the goal of the Charter - to ensure human dignity. Finding that the denial of benefits to those under thirty did not perpetuate the view that they were less worthy of concern and respect nor impose stereotyping or political or social prejudice, the Court found no Charter violation.

Two months after the decision in Law v. Canada, the Court applied its new s. 15(1) analysis to the case of $M$. v. $H$. $M$. and $H$. are women that lived together in a conjugal relationship of economic interdependence for approximately five years. Upon the deterioration of their relationship in 1992, M sought an order for partition and sale of the couple's house, asserted a claim for spousal support pursuant to the Family Law $A c t,{ }^{7}$ and she also gave notice that she was challenging the constitutional validity of s. 29 of the $F L A$. Her challenge called for an expansion of the definition of spouse used in s. 1 of the $F L A$, which restricted the term to "either of a man and woman who are not married to each other and have cohabited for a period of not less than three years...." In 1996, the Ontario Court (General Division) ruled that the $F L A$ violated s. 15(1) of the Charter and was not saved by s. (1). This decision was appealed by H, who was joined by the Attorney General of Ontario as an intervenor. The Court of Appeal upheld the decision that the FLA violated the Charter. The Attorney General then appealed this decision to the Supreme Court of Canada, which upheld the finding of a s. 15(1) violation that was not saved by s. 1 and declared s. 29 of the FLA to be of no force and effect. 


\section{B. Defining Equality}

Vriend, Law and $M$. v. $H$. provide an excellent context in which to trace the evolution of the Court's approach to interpreting s. 15(1) challenges and to examine the Court's definition of equality and how it should be recognized. Section 15(1) of the Charter specifies that:

Every individual is equal before and under the law and has the right to the equal protection and equal benefit of the law without discrimination and, in particular, without discrimination based on race, national or ethnic origin, colour, religion, sex, age or mental or physical disability."

This section of the Charter establishes the four equalities that must be upheld by governments in applying laws to individuals - the right to equality under the law, equality before the law, equal protection of the law, and equal benefit of the law - and specifies that these equalities may not be violated on the basis of certain personal characteristics. The form of equality sought by the Charter goes beyond the concepts of formal equality and of equal opportunity to that of substantive equality. As explained by equality scholars Lynn Smith and William Black, ${ }^{10}$ formal equality consists of applying a law equally to individuals as the law provides, even though direct discrimination against groups may result. Formal equality does not concern itself with the purpose of the law; instead, it justifies even invidious discrimination as long as it discriminates against everyone in a particular group equally. A law that confers a benefit on one gender explicitly on the basis of sex may meet the test of formal equality as long as all members of that group are subject to the benefit or sanction of the law equally.

The idea of formal equality as the desired form of equality for a society to achieve has long been abandoned, as has the goal of equal opportunity equality. Equal opportunity equality is a more progressive formulation of equality that eliminates direct discrimination by allowing everyone the equal opportunity to enjoy fundamental rights such as voting and education and employment, " but has a major shortcoming in that it often fails to recognize adverse effect discrimination. Legislation that is facially neutral may appear to provide the opportunity for all members of society to enjoy an advantage but may effectively deny that advantage by failing to consider differences based on personal characteristics, such as gender, historical disadvantage or religion. ${ }^{12}$ In the 1980s, noting the failure of equal opportunity equality to address concerns of disadvantaged groups, the law embraced the idea of substantive equality. Justice Beverly McLachlin explains the commitment to substantive equality thus:

". L. Simith \& B. Black, "The Equality Rights" in G.A. Beaudoin \& E. Ratushny, eds., The Canadian Charter of Rights and lireedoms, 3d ed. (Toronto: Carswell, 1996) c. 14.

"The most famous case introducing this approach being the judgment in Brown v. Board of Education of Topeka, 347 U.S. 483 (74 S.Ct. 686) (1954).

12 Comprehensively addressed by the Court in Ontario (Human Rights Commission) v. Simpson-Sears Ltd., [1985] 2 S.C.R. 536. 
[I]t is the belief that if equality is to be realized, we must move beyond formal legalism to measures that will make a practical difference in the lives of members of groups that have been traditionally subject to the tactics of subordination.... The use of the law to promote substantive equality, the phase we presently find ourselves in, takes two forms. The first is legislated programs whereby government, social and economic institutions are encouraged or, in some cases, required, to include people of underrepresented groups. The second is the judicial concept of substantive equality, developed by the courts in Andrews v. Law Sociery of British Columbia and subsequent cases."

In the early 1980s, the Charter, in particular s. 15(2), which provides that equality rights in s. 15(1) do "not preclude any law, program, or activity that has as its object the amelioration of conditions of disadvantaged individuals or groups," 14 promised to be the means by which substantive equality in Canada could be achieved. Prior to the Supreme Court hearing its first equality case in 1989, however, there was no consensus on what analytical framework should be used to determine if s. 15(1) rights were being violated. Worried about the potentially limitless flood of litigation that was possible under s. 15(1), the courts were inclined to treat every distinction created by law as a subject for consideration under the Charter and deal with them in one of two unsatisfactory ways. Courts tended to uphold most claims against s. 15(1) either by finding that almost all distinctions drawn by laws were discriminatory and then focusing consideration of the reasonableness of the impugned law under s. 1 , where the discrimination was often found to be justified, ${ }^{15}$ or by finding that the distinctions created were reasonable and not discriminatory under s. 15(1), thus greatly minimizing the role of s. $1 .^{16}$

By 1988, just three years after having come into effect, some 591 cases in Canada had been heard that challenged a law on the basis of s. 15(1). ${ }^{17}$ Most of these were unsuccessful, but the s. 15(1) challenge was becoming an automatic reflex for lawyers whenever their clients' interests were not served by the law. By the late 1980s, it was evident that the Supreme Court of Canada needed to set guidelines for the other courts on how to apply s. 15(1).

\section{Creating the Analytical framework: ANDREWS}

Although the Charter of Rights and Freedoms came into force in 1982, the equality provision, s. 15, did not come into effect until three years later on 17 April 1985. This was done in order to give the federal and provincial governments sufficient time to amend any legislation or programs that were inconsistent with the section. As a result, it was not until 1989 that the first equality case came before the Supreme Court. Mr. Andrews, challenging the British Columbia government's legislation ${ }^{18}$ that made

B. McLachlin, "The Evolution of Equality" (1996) 54 Advocate 563.

Supra note 9, s. 15(2).

An approach often associated with Dean Peter Hogg, who forwarded an interpretation that denied any real function to s. 15(1) in early Charter jurisprudence.

An approach best illustrated by McLachlin J.A.'s judgment in Andrews v. The Law Society of British Columbia (1986), 2 B.C.L.R. 305, 27 D.L.R. (4th) 600 (B.C.C.A.).

P.W. Hogg, Constitutional Law of Canada, vol. 2 (Toronto: Carswell, 1997) at c. 52 at 16.

Barristers and Solicitors Act, R.S.B.C. 1979, c. 26, s. 42. 
Canadian citizenship a requirement to be a member of the B.C. Law Society and thus to practice law, argued that he was being discriminated against on the basis of his status as a non-citizen of Canada. Although this requirement was not found to violate the Charter by the British Columbia Court of Appeal, Andrews appealed to the Supreme Court of Canada where a majority of judges upheld his claim. The six judges who participated in the decision ruled unanimously that the legislation did violate his rights under s. 15(1), although two judges decided that this violation was demonstrably justified under s. 1 .

The judgment of McIntyre $\mathrm{J}$. in Andrews provided the analytical framework that would be used to decide this case and further equality cases in the following years. Although the members of the Court were unanimous in their adoption of his s. 15(1) analysis, several would later rethink this approach, causing many academics to question the Court's commitment to substantive equality. In order to understand the significance of the Court's approach in Vriend and Law, it is essential to examine both the analytical framework that McIntyre J. established for evaluating s. 15(1) challenges and how the members of the Court later modified it, retained it, or expanded the scope of it in subsequent cases.

Prior to embarking on an analysis of any section of the Charter, a court must first establish that it has jurisdiction in the matter and that the Charter applies. This process determines whether or not the claimant has standing. For the purposes of s. 15(1), the claimant must establish that it is the operation of a government function, such as law making or the operation of a program, that creates the distinction alleged. The text of the Charter is quite clear in specifying that it applies to the public and not the private sphere:

This Charter applies (a) to the Parliament and Government of Canada in respect of all matters within the authority of Parliament including all matters relating to the Yukon Territory and Northwest Territories; and (b) to the legislature of cach province in respect of all matters within the authority of the legislature of each province."

In the instance of Andrews, it is obvious that the Charter applied as the distinction that he was challenging was created by a statute that explicitly restricted the profession of law to citizens of Canada. Defining when the Charter applies to indirect government actions, such as the operation of federally and provincially funded agencies and institutions, is a more problematic matter. Prior to the judgment in Vriend, some thought that s. 32 might prove to be a barrier to certain claims as the wording of this section is ambiguous as to whether the Charter applies to instances of legislative silence. ${ }^{20}$ The Court's recent decision in Eldridge v. British Columbia, ${ }^{21}$ indicating that the Charter applies to a failure of a government agency to use its discretion to implement a specific policy, and the reading in that occurred in Vriend indicates that

19 Supra note 9, s. 32(1).

21 For a more detailed examination, see R. Elliot, "Scope of the Charter's Application" (1993) 15 Advocates' Q. 204.

21 [1997] 3 S.C.R. 624 [hereinafter Eldridge]. 
this problem has been resolved by the Court and that the Charter can apply to government inaction as well as government action.

\section{A. Step ONE: Establishing Distinction}

In the Andrews decision, Dickson C.J. and Lamer, Wilson, La Forest and L'HeureuxDubé $\mathrm{JJ}^{22}$ adopted the two-step approach to analyzing s. 15(1) claims that was introduced and written by McIntyre J. The first step of the analytical framework requires determining if the legislation or program that is being challenged draws a distinction that violates one of the four rights guaranteed by the section: the right to equality before and under the law, and the right to equal protection and benefit of the law. Charter jurisprudence dictates that the claimant must be asserting a violation of an equality right against the government and not against a private actor, although a claim may be asserted against government legislation that permits a private actor to violate an individual's equality right, as is the case in Vriend. Further, s. 15(1) clearly indicates that the claimant must be an individual and not a corporation or other artificial body.

The first step in determining equality rights requires a claimant to establish that a distinction creating a disadvantage for the claimant through the violation of one of the equality rights does exist. To establish distinction, it is not necessary to consider the intent of the law, but rather the effect, recognizing that distinction can be either purposeful or unintentional. To establish distinction is not difficult: one must merely prove that a law or program is treating an individual or group differently from others. Thus the Income Tax Act creates a distinction by charging those with a higher income a higher proportional tax rate, economically disadvantaging them relative to lower income earners. A distinction is also created when a law allows citizens to practice as lawyers and refuses to allow non-citizens to do so, despite their professional qualifications.

Distinction should not be understood as a disadvantage to a group or individual relative to others in a similar situation, but as the deleterious effect on the party relative to the rest of society. A law that treats "likes" alike and "unlikes" unalike is one that draws a distinction. Although it may advantage one party, if that distinction disadvantages another party, it is not substantially equitable, although it may be formally equitable. For example, a law that refuses to grant paid sick leave to those members of the workforce that are pregnant may be formally equitable and said not to draw distinctions, as no individual is receiving maternity benefits. It may thus pass the similarly situated test, as everyone in a similar situation of pregnancy would have the same amount of benefits. ${ }^{23}$ But such a law examined in the analytical framework of Andrews, would draw a distinction as it has the effect of adversely effecting women, the only sex that can become pregnant. In Andrews, the similarly situated test, as understood by McIntyre J., is expressly addressed and rejected in his judgment:

$22 \quad$ Le Dain J. sat on the case but took no part in the judgment.

23 As was the result in Bliss v. Allorney General of Canada, [1979] 1 S.C.R. 183 [hereinafter Bliss]. 
Thus, mere equality of application to similarly situated groups or individuals does not afford a realistic test for a violation of equality rights. For, as has been said, a bad law will not be saved merely because it operates equally upon those to whom it has application. Nor will a law necessarily be bad because it makes distinctions. ${ }^{24}$

From the detailed examination of the meaning of equality, it is clear that McIntyre J. intended s. 15(1) of the Charter to be used for the purpose of correcting past patterns of social inequality by adopting a much broader scope of distinction than had been traditionally followed, although it is arguable that McIntyre J.'s understanding of some of the concepts such as formal equality and the similarly situated test were not properly articulated in this judgment. Having established the criteria for determining a distinction, a disadvantage suffered by infringement of one of the four equality rights, McIntyre J. introduced the second step in his analytical framework.

\section{B. SteP Two: Establishing Discrimination}

To establish discrimination, the claimant must demonstrate the distinction established in step one is being made on the basis of either one of the "enumerated grounds," those listed in s. 15(1): race and national or ethnic origin, colour, religion, sex, age, mental or physical disability or an "analogous ground," personal characteristics that are similar to the ones listed. In Andrews, while it was possible to argue that citizenship could be included in the enumerated ground of national origin, the Court expanded the application of the section to include protection from discrimination based on citizenship.

Distinction is not synonymous with discrimination and, as in the aforementioned example of a distinction created by a law requiring those with a higher income to pay a higher percentage of income in taxes relative to those with lower incomes, the existence of distinction is not sufficient to create discrimination. Central to the idea of discrimination is the importance of recognizing that there are certain characteristics that are immutable, such as race, others that are changeable only at great personal cost, such as religion, or of a changeable status that an individual has no direct control over, such as citizenship. The Court recognizes that the list in s. 15(1) is not exclusive and that to develop an exhaustive list would be difficult, especially considering the difficulties in identifying certain types of discrimination, such as systemic discrimination.

With the support of the others on the Court, McIntyre J. established a broad basis upon which distinction may be recognized as discrimination, one that is neither too permissive, as was the criticism with Hogg's formulation, nor too restrictive, as was the case with the McLachlin application:

I would say then that discrimination may be described as a distinction, whether intentional or not but based on grounds relating to personal characteristics of the individual or group, which has the effect of imposing burdens, obligations, or disadvantages on such individual or group not imposed upon others, or which withholds or limits access to opportunities, benefits, and advantages available to other members of society. Distinctions based on personal characteristics attributed to an individual solely on 
the basis of association with a group will rarely escape the charge of discrimination, while those based on an individual's merits and capacities will rarely be so classed."

The conclusion reached after applying this two-step framework for analyzing s. 15(1) challenges is, as are all Charter claims, subject to scrutiny under s. 1 of the Charter. At this point, four members of the Court, Dixon, La Forest, Wilson and L'HeureuxDubé JJ., diverged from McIntyre J., making his judgment a dissenting opinion. McIntyre J.'s reasons were concurred with by Lamer C.J. in separate reasons. Having established that the impugned law drew a distinction that disadvantaged Mr. Andrews and that the distinction was based on an analogous ground, the Court considered whether or not this discrimination was within a reasonable limit that was demonstrably justified in a free and democratic society. The majority found that it was not.

\section{Section One Justification}

Having passed the test for the individual section of the Charter being challenged, claimants must then pass the $s$. 1 threshold, that of justification for the restriction on the merits of its purpose and method. In Charter jurisprudence, the burden of proving that a violation of the Charter has occurred is always placed on the claimant, and, if a violation is established, the party seeking to uphold the impugned law has the burden of justifying its continuing application under s. 1 . Section 1 provides that:

The Canadian Charter of Rights and Freedoms guarantees the rights and freedoms set out in its subject only to such reasonable limits prescribed by law that can be demonstrably justified in a free and democratic society. ${ }^{20}$

The test for determining whether or not violations of rights are demonstrably justified in a free and democratic society was developed by Dickson CJ. in R. v. Oakes, ${ }^{27}$ and was articulated by Wilson $\mathrm{J}$. in her judgment in Andrews as being applied in two stages. In the first stage, the party seeking to uphold the violation must demonstrate that the "objective sought to be achieved by the impugned law must relate to concerns which are "pressing and substantial" in a free and democratic society." The second stage involves the application of "a proportionality test which requires the Court to balance a number of factors. The Court must consider the nature of the right, the extent of its infringement, and the degree to which the limitation furthers the attainment of the legitimate goal reflected in the legislation." ${ }^{28}$

In Andrews, the majority found that the legislation's objective of recognizing the importance of the legal profession in the governance of society and its vital role in the administration of justice was a legitimate goal, but that the proposed measures of prohibiting qualified individuals from practising law on the basis of their citizenship did not meet the Oakes mandated criteria of minimal impairment of rights, rational 
connection, or proportionality of means to ends. In contrast, McIntyre J. and Lamer C.J. felt that restricting the practice of law to citizens in order to ensure that lawyers were familiar with, loyal to and had stake in the institutions of the government and judiciary was a reasonable limit that met the Oakes proportionality requirements of rational connection, minimal impairment and proportionality between the effects and the objective sought. This was primarily because citizenship, although not readily determinable by the individual, is eventually granted to permanent residents so that the discrimination is not permanent.

\section{Tile POST ANDREwS Period}

After seeing the analytical framework for evaluating Charter cases that was established and unanimously adopted by the Court in Andrews, many were pleased that the Court had adopted such a progressive attitude in embracing substantive equality. In the years after Andrews was heard, some members of the Court re-evaluated the approach in that case and modified it, resulting in a three way split. Commenting on a series of decisions, dubbed "the equality trilogy of 1995," some observers argued that the Court had retreated from its previous progressive stance and was rethinking its conception of equality.

Although it is beyond the scope of this paper to examine the entire judicial history of analyzing s. 15(1) claims, a brief indication of the trend of the courts following Andrews is helpful. Other cases released in 1989 seemed to indicate that the commitment to substantive equality demonstrated by the Court was real. The decisions in Brooks v. Canada Safeway Ltd., ${ }^{29}$ in which the Court ruled that a denial of employee benefits to pregnant workers was discriminatory, effectively overruling the similarly situated approach as adopted in the pre-Charter Bliss that dealt with the same issue ${ }^{30}$ and the ruling in Janzen v. Platzy Enterprises, ${ }^{31}$ in which the Court ruled that sexual harassment was sexual discrimination, are cases supporting this position.

In the 1990s, some could argue that even if the similarly situated test had been explicitly abandoned, some elements of it remained. In R. v. Hess and R. v. Nguyen, ${ }^{32}$ the Court, with the majority writing through Wilson J., held that a criminal law that applies to only one sex by making it an offence for a male to have sex with a female under fourteen was not discriminatory. Her argument was that as a "matter of fact" the law prohibited an act that could only be committed by one sex because of biological differences between genders; only men could perform the act of penetration. Wilson J. thus justified treating men differently than women because only men could perform the act of penetration and denied young males the protection offered to young females. Such an argument brought the Court closer toward the similarly situated test that Andrews had promised to avoid, which justified different treatments on the grounds that 
the two sexes were not similar. ${ }^{33}$ Similarly, the criticism levelled against the Court for decisions such as its failure to allow child care expenses as a business expense deduction for income tax purposes on the grounds that such a failure was not discrimination based on $\operatorname{sex}^{34}$ would only increase after the judgments it released in 1995.

\section{Rethinking the ANALytical Framework: THE EQUALITY TRILOGY OF 1995}

The greatest criticism that the Court has received from proponents of substantive equality came in the wake of its decisions in the spring of 1995 when the Supreme Court revisited the framework established by Andrews ${ }^{35}$ for the application of $s .15(1)$ in a trilogy of cases: Miron v. Trudel, ${ }^{36}$ Egan and Nesbit v. Canada ${ }^{37}$ and Thibaudeau v. Canada. ${ }^{38}$ The facts, and indeed the outcomes, of the specific cases are not as important as the different approaches that were used to adjudicate them. In this trilogy of cases, the Court split into three camps, and it is most useful to examine the judgments from each judicial perspective adopted, rather than by examining each case individually. The three approaches to the original analytical framework adopted in the trilogy are that of maintaining it, expanding the scope of it, and modifying it by including a third step that assesses relevance.

Miron dealt with the conveyance of accident insurance benefits on spouses. In this case, a system that awarded benefits to married spouses and not common law spouses was challenged as discriminatory. It was subject to Charter scrutiny because the terms of the policy are governed by federal legislation, the Insurance $A c t .^{39} \mathrm{~A}$ majority of the Court was prepared to add marital status as an analogous ground protected by the Charter, find a violation of s. 15(1) and decide that the discrimination was not justified under s. 1 .

Egan challenged the definition of "spouse" in the federal Old Age Security $A c t^{40}$ on the grounds that it discriminated on the basis of sexual orientation by limiting the definition of spouse to couples of the opposite sex. Although, significantly for Vriend, the Court found unanimously that sexual orientation was an analogous ground, the legislation was upheld. A majority of five out of nine judges found that the law violated s. 15(1), but only four of these held that the violation was not justified under s. 1, causing the challenge to fail.

For a more detailed analysis of the period between Andrews and the equality trilogy of 1995, see A. York, "The Inequality of Emerging Charter Jurisprudence" (1996) 54 U.T. Fac. L. Rev. 327. Symes v. Canada, [1993] 4 S.C.R. 695.

The judgment in Andrews established the basic framework and was more fully developed in $R$. v. Turpin, [1989] I S.C.R. 1298 and $R$. v. Swain, [1991] I S.C.R. 933. For the purposes of this paper, the Andrews test includes the clarifications made to it by these two cases.

[1995] 2 S.C.R. 418 [hereinafter Miron].

[1995] 2 S.C.R. 513 [hereinatter Egan].

[1995] 2 S.C.R. 627 [hereinafter Thibaudeau].

R.S.O. 1980. c. 218 , ss. 231,233 , sch. C.

R.S.C. 1985, c.0-9, rep. R.S.C. 1985 (1st Supp.), c. 34, s. 1(1). 
Thibaudeau challenged the provisions of the Income $\operatorname{Tax} \mathrm{Act}^{41}$ that required the parent with custody of a child to declare support payments as taxable income as discriminatory on the basis of parental status, with a number of intervenors additionally challenging the law on basis of sexual discrimination because most custodial parents were women. The Court, in a split along gender lines, delivered a majority judgment that the Act discriminated neither on sex nor on parental status.

\section{A. MOdifying THE FRAMEWORK: \\ LAMER, LA FOREST, GoNTHIER AND MAJOR}

\section{Thr: New Three Step Approach}

The four justices, writing through Gonthier J. in Miron and Thibaudeau ${ }^{42}$ and through La Forest J. in Egan, who applied Gonthier J.'s treatment, adopted the analytical framework of Andrews, but significantly modified it by adding a third step to the two step analysis of McIntyre J. In the first step of McIntyre J.'s evaluation of s. 15(1) claims, distinction resulting in disadvantage through a violation of one of the four equality rights must be established. In the second step, discrimination is established through demonstrating that the distinction is based on an enumerated or analogous ground. Having established discrimination, McIntyre J. would have then proceeded to s. I justification but Gonthier J. saw the necessity of introducing another step.

Not only did Gonthier J. add a new step to McIntyre J.'s analytical framework, he also modified the second step. The first step establishes that a distinction is drawn by the law between the claimant and others; the second step determines if that distinction results in a disadvantage that is imposed on a group of persons to which the claimant belongs;

The third step assesses whether the distinction is based on an irrelevant personal characteristic which is either enumerated in $\mathrm{s} .15(1)$ or one analogous thereto... This third step thus comprises two aspects: determining the personal characteristic shared by a group and then assessing its relevancy having regard to the functional values underlying the legislation."

Gonthier J. advocated reformulating the test in Andrews by finding that discrimination will only exist when a distinction is based on a characteristic irrelevant to the purposes of the legislation, largely importing the s. 1 consideration into s. 15(1). Discrimination can only be found to occur when a distinction is made that is irrelevant to the values served by the legislation:

The second aspect of the third step, that of assessing relevancy, looks to the nature of the personal characteristic and its relevancy to the functional values underlying the law. Of course, the functional values underlying the law may themselves be discriminatory. Such will be the case where the

12 Major J. and Lamer J. did not sit on the Thibaudeau case.

4 Miron, supra note 36 at $435-36$, Gonthier J. 
underlying values are irrelevant to any legitimate legislative purpose. Relevancy is assessed by reference to a ground enumerated in $\mathrm{s}$. 15 or one analogous thereto. ${ }^{4 t}$

He argued that finding distinctions on such grounds is not discriminatory if they are relevant to "the expression of some objective physical or biological reality or fundamental value." ${ }^{.45}$ In Miron, Gonthier J. found that the functional value underlying the legislation is the recognition of the distinction of martial status and the fact that there are many benefits and disadvantages attributed to couples living in a married as opposed to a common law relationship. Since the distinction being drawn is relevant to the purpose of the legislation being drawn, it is not discriminatory. Gonthier J. also made the somewhat more compelling argument that since entry into marriage is voluntary, marital status is not an analogous ground for the purposes of s. 15(1).

In Egan, La Forest J. adopted the same test to discover that while sexual orientation is an analogous ground for the purposes of s. 15(1), the distinction created by not conferring a benefit on that basis is not discriminatory. He found the functional value underlying the definition of spouse in the Old Age Security Act to be the importance of marriage and recognizing that "marriage is by nature heterosexual" and noting that "[i]t would be possible to legally define marriage to include homosexual couples, but this would not change the biological and social realities that underlie the traditional marriage. ${ }^{946}$

So while a distinction exists that disadvantages a group, homosexuals, it is on the basis of relevant characteristics, therefore not discriminatory. In Thibaudeau, Gonthier J. found the distinction drawn by forcing parents receiving custodial support to pay income tax was not a disadvantage as it conferred a net benefit to the family unit, so it was unnecessary to consider if the distinction was relevant to underlying functional values or not.

\section{IMPLICIT ADOPTION OF THE SIMILARLY SITUATED TEST}

Although a common thread running through every s. 15(1) case is an explicit rejection of the similarly situated approach to equality, the modified approach of Lamer, La Forest, Gonthier and Major JJ. can be seen to implicitly adopt it or at least key elements of it. To appreciate this approach, it is important to recognize that McIntyre J.'s articulation of the similarly situated approach in Andrews is not entirely accurate. His conception more closely resembles the Aristotelian idea of formal equality than that of similar situation as understood and employed widely in the United States today:

The similarly situated test is a restatement of the Aristotelian principle of formal equality - that "things that are alike should be treated alike, while things that are unalike should be treated unalike in proportion to their unalikeness".... The test as stated, however, is seriously deficient in that it

$44 \quad$ bid. at 436 .

4 Ibid. at 438 .

4. Supra note 37 at 5365 , La Forest J. 
excludes any consideration of the nature of the law. If it were to be applied literally, it could be used to justify the Nuremberg laws of Adolf Hitler. Similar treatment was contemplated for all Jews. ${ }^{47}$

It is hardly surprising that Gonthier and La Forest JJ. would not wish association with the principle as articulated by McIntyre J., in light of the connotation that he has given it. McIntyre J., however, fails to consider that the similarly situated approach can be made with purposeful contemplation of the values that it seeks to uphold. Further evidence of his mixing similar situation with formal equality is delivered later in Andrews:

[T] [ [similarly situated] test cannot be accepted as a fixed rulc or formula for the resolution of equality questions arising under the Charter. Consideration must be given to the content of the law, to its purpose, and its impact upon those to whom it applies, and also upon those whom it excludes from its application. The issues which will arise from case to case are such that it would be wrong to attempt to confine these considerations within such a fixed and limited formula."

The judgments of Gonthier and La Forest $\mathrm{JJ}$. demonstrate that their analytical framework considers both the purpose and content of the law. Indeed, the content and purpose of the law is more important than its effect, allaying the concerns articulated by McIntyre J. It is apparent that McIntyre J.'s definition of the similarly situated test is one that few would be anxious to adopt or be proponents of and it is also apparent that Gonthier and La Forest JJ.'s approach do not match. The proper formulation of the similarly situated test, used in the United States by courts applying the Fourteenth Amendment to the Constitution of the United States of America, which guarantees equal protection of the law, is as follows:

The concept of the equal protection of the law compels recognition of the proposition that persons similarly situated with respect to the legitimate purpose of the law receive like treatment. This concept does not, however, require absolute equality or that a statute necessarily apply equally to all persons; rather, it permits a state to provide for differences so long as the result does not amount to an invidious discrimination."

That the term similarly situated is politically charged is evident; equally evident is that it has more than one meaning. To clarify, the one used in this paper is similar to the definition used in United States and as practised, though not so cited, by Gonthier and La Forest JJ. Similar situation is an approach that Peter Hogg refers to as the "doctrine of reasonable classification," which he articulates as meaning that if a law serves a legitimate purpose and employs classifications that are reasonably related to the accomplishment of that purpose then there is no violation of equal protection of the law. ${ }^{50}$ Applying the reasonable classification doctrine to Egan results in the same outcome that La Forest J. achieves: employing a classification of spouse as an opposite 
sex partner is reasonable to the purpose of promoting heterosexual marriage and therefore not discriminatory.

The process of classification requires that some criteria must be used to decide how the classification is applied and how the claimant's group will be defined. Such a process necessarily requires placing them in comparison to another group. This means either similarly situating the claimant in the position of a group that is not affected by the distinction and thereby making a distinction an irrelevant one; alternately, situating the claimant in a dissimilar position to a group that is not affected by the distinction, thereby making that distinction a relevant one. To illustrate with Egan, the result achieved depends on where the claimants are situated, which depends upon their classification. If homosexual and heterosexual couples are classified together as "people," they are then placed in a similar situation, making the distinction that adversely effects homosexuals an irrelevant one. To use the terminology of the similarly situated approach: groups in a similar situation are not receiving a similar benefit. To phrase the situation in terms of the doctrine of reasonable classification: since the classification used is related to the accomplishment of the purpose sought, the classification used is therefore reasonable. Assuming that the underlying functional value of, or purpose sought by, the Old Age Security Act is the provision of income to people in their old age, then these classifications and situations make sense.

If, however, the underlying functional value of, or purpose served by, the Old Age Security $A c t$ is to promote heterosexual relationships, then the classifications or situations used above are not acceptable. If homosexual and heterosexual couples are classified apart as "spouses" and "non-spouses," they are then placed in a dissimilar situation, making the distinction that adversely effects homosexuals a relevant one. To use the terminology of the similarly situated approach: groups in a dissimilar situation are not receiving a similar benefit. To employ the doctrine of reasonable classification: the classification used is related to the accomplishment of the purpose sought, so the classification used is therefore reasonable.

Whether the similarly situated approach is articulated as the reasonable classification doctrine as per Hogg, or the relevance to underlying functional values approach as per Gonthier and La Forest JJ., one can see a fundamental flaw with the process. Finding discrimination depends on the definition of the purpose of the law and the classification of the claimant employed. Since both these criteria are subjective and there is no specified method for determining them, there is a real danger that the approach can be manipulated to achieve a desired result.

Gonthier J. in Miron and La Forest J. in Egan achieved the same result that the similarly situated test, properly understood, does. Gonthier J. argued that insurance benefits should not be extended to common law spouses because of the differences between common law relationships and marriages. He cited as evidence that "[i]n addition to resting upon a consensual, contractual basis, marriage is a status to which the legislature, as a reflection of its social policy, attaches a bundle of rights and 
obligations." While the similarities between the two statuses are greater than the differences, Gonthier J. emphasized the differences in order to argue that the benefit should not be extended because of the dissimilarities of the parties. In placing the groups in a dissimilar situation, he made those dissimilarities relevant to the underlying functional values of the legislation, as determined by him, and he could thereby justify finding the distinction non-discriminatory.

In Egan, La Forest J. offered another example of how Gonthier J.'s s. 15(1) analysis mirrors the similarly situated approach. An emphasis is placed upon demonstrating the differences between the traditional institution of marriage and the competing value in Miron, common law marriage and in Egan, homosexual marriage. La Forest J. did more than illustrate the difference, while largely ignoring the similarity, between heterosexual and homosexual couples; he also emphasized how homosexuals are similarly situated to other social pairs, in that they are non-heterosexual:

I fail to see how homosexuals differ from other excluded couples in terms of the fundamental social reasons for which Parliament has sought to favour heterosexuals who live as married couples. Homosexual couples, it is true, differ from other excluded couples in that their relationships include a sexual aspect. But this sexual aspect has nothing to do with the social objectives for which Parliament affords a measure of support to married couples and those who live in a common law relationship.... Homosexual couples are not, therefore, discriminated against; they are simply included with these other couples. 52

La Forest $\mathrm{J}$. documented the greater role that heterosexuals play in society by raising children and used this as evidence of the functional values underlying the definition of spouse in the Old Age Security Act, that of recognizing and promoting the traditional family. It is important to realize that both Gonthier J. and La Forest J. determined the underlying functional values in relation to the specific section being challenged and not the legislation as a whole. Comparing the approach as articulated here to the decision in Vriend, as will occur later, provides evidence that La Forest J. and Gonthier J. have either rethought their application of the analytical framework or apply it inconsistently. In Vriend, the approach used as articulated here would have resulted in upholding the claim of the Alberta government instead of finding for the claimant.

By definition, the similarly situated approach used by Gonthier and La Forest JJ. requires comparison between groups, something that is achieved by stating the need to "contextualize" decisions. This contextual approach means that the Court must discover, or create, the fundamental values that will allow distinctions to become relevant and therefore non-discriminatory. Under this approach, there is almost no role for $s .1$ of the Charter as considerations of the relevance of the discrimination in the s. 15(1) stage pre-empt the minimal impairment, proportionality, and rational connection tests mandated by Oakes. Ironically, this approach is remarkably similar to McLachlin J.'s formulation of the equality test in the Andrews case at the British Columbia Court of 
Appeal, heard almost a decade before, one that was rejected by both a unanimous Court when it was appealed in 1989 and by McLachlin J. in her judgments in these cases.

\section{B. Maintaining the Framework: MClaChlin, IACOBuCCI, CORY AND SOPINKa}

While the reasons of this group of judges were not as uniform as those of Lamer, Gonthier, La Forest and Major JJ., they, as a whole, demonstrated the commitment to substantive equality sought in the analytical framework developed in Andrews, and with L'Heureux-Dube' J., delivered a strong criticism of the approach of the other four judges. Although McLachlin, Iacobucci, Cory and Sopinka JJ. came to different conclusions in some of the cases, they adopted a similar, though not identical methodology throughout, differing only in their application of the facts to the case, as in McLachlin J.'s dissent in Thibaudeau, or in their justification of discrimination under s. 1, as in Sopinka J.'s judgment in Egan.

McLachlin J., writing for this coalition of judges in Miron, used her judgment both to affirm the Andrews approach and to critique the new three step approach of Gonthier $\mathrm{J}$. and La Forest J. Her criticism is two fold. First, the approach differs substantially from the previously established analytical framework in that it fails to consider the effect of the distinction upon historically disadvantaged and stereotyped groups by placing undue emphasis on the purpose of the legislation. She believes that the purpose of the Charter "is to prevent the imposition of limitations, disadvantages, or burdens through the stereotypical application of presumed group characteristics in violation of human dignity and freedom." 53 Unlike Gonthier J. and La Forest J., she believes the concern must be placed on the effect and not the purpose of the legislation.

Her second criticism of the other group of judges is regarding the logic of the means used to discover the underlying fundamental values of impugned laws and to assess their relevance. Commenting on Gonthier J.'s determination that the underlying functional value of the Insurance Act's allocation of benefits is to recognize those couples that are married and not to provide support for all family units in a state of financial interdependence, McLachlin J. offers the following critique:

He [Gonthier J.] concludes that distinguishing on the basis of marital status is relevant to this purpose and hence the law is not discriminatory. On examination, the reasoning may be seen as circular. Having defined the functional values underlying the legislation in terms of the alleged discriminatory ground, it follows of necessity that the basis of the distinction is relevant to the legislative aim. This illustrates the aridity of relying on the formal test of logical relevance as proof of non-discrimination under s. 15(1). The only way to break out of the logical circle is to examine the actual impact of the distinction on members of the targeted group. ${ }^{54}$

It is the third step of the Gonthier and La Forest JJ. test, testing relevance, that was most troubling for McLachlin J., not only for its circular logic but also because of the 
increased burden that it places upon the claimant. Cory and Iacobucci JJ. were particularly concerned about the third step as it imports the test of justifying the distinction made from s. 1 into s. 15(1). Under the Oakes test, as applied in Andrews, the claimant has to prove disadvantage on an enumerated or analogous s. 15(1) ground to establish discrimination. At this point, the burden shifts to the party seeking to uphold the discrimination, who has to justify its continuance under a separate and well reasoned framework in s. 1. By placing relevance in the s. 15(1) analysis, the need to justify the legislation by the Oakes criteria is effectively eliminated.

Under the Gonthier and La Forest JJ. formulation, a claimant must anticipate which underlying functional values will be served by the legislation and attempt to prove that the distinction made is irrelevant. If the underlying functional value is judged to be the desire to promote a certain form of social organization, then the claimant must try to prove similarities with a group in that organization that is not disadvantaged, for once a group is similarly situated, then the distinction made becomes irrelevant. For example, in Miron, where the underlying functional value was promoting legal marriage, the burden was placed on the claimant to prove irrelevance of the distinction, which could only really be done by demonstrating a similar situation of common law to married couples. Likewise in Egan, where the underlying functional value was the importance of heterosexual marriage, the burden was placed on the claimants to prove similarity with heterosexual couples and thus demonstrate irrelevance of the distinction.

Justifying discrimination under s. 1 of the Charter is a more appropriate method of upholding legislation than finding that discrimination does not exist. Sopinka J., for example, found in Egan that a distinction which confers a disadvantage on a group based on an analogous group is discriminatory and then seeks to justify that discrimination under the principles of Oakes. Although it is laudable that Sopinka J. places the justification for the reasonableness of discrimination in a $\mathrm{s} .1$ analysis instead of importing it into s. 15(1) as Gonthier and La Forest JJ. have done, he received criticism from Iacobucci J. for his method. In Egan, Iacobucci J. criticized Sopinka J. for straying from the principles of Oakes and for misapplying the principles of incrementalism from McKinney v. The University of Guelph ${ }^{55}$ and legislative deference from Irwin Toy v. Quebec (A.G.).: ${ }^{56}$

\footnotetext{
Permitting discrimination to be justified on account of the "novelty" of its prohibition or on account of the need for governmental "incrementalism" introduces two unprecedented and potentially undefinable criteria into $\mathrm{s}$. 1 analysis. It also permits s. 1 to be used in an unduly deferential manner well beyond anything found in the prior jurisprudence of this Court. The very real possibility emerges that the government will always be able to uphold legislation that selectively and discriminatorily allocates resources. This would undercut the values of the Charter and belittle its purpose. ${ }^{37}$
}

While Sopinka J. received wide criticism from many groups for his statement that homosexual marriage was "a novel concept" that should be introduced incrementally, 
he should be credited for recognizing that justification of discrimination must take place in the context of an established framework that considers the factors of minimal impairment, proportionality and rational connection of means to ends instead of the more ambiguous and subjective test of relevance to underlying functional values. Though Sopinka, McLachlin, Cory and Iacobucci JJ. do not come to a consensus on the result of each case, their commitment to the analytical framework of Andrews is clearly demonstrated.

A number of authors, such as Andrea York ${ }^{58}$ and Leon Trakman, ${ }^{59}$ have indicated that McLachlin J.'s analysis, determining discrimination based on whether the claimant received unequal treatment by virtue of membership in a group subject to stereotypical treatment, constitutes a sufficiently different analysis from Sopinka, Iacobucci and Cory $\mathrm{JJ}$. to categorize her analytical framework as a fourth category, more progressive than the other judges' approach but less so than L'Heureux-Dubé J.'s. Examining the posttrilogy judgments, this approach make sense as L'Heureux-Dubé and McLachlin JJ. offer dissents in two out of eight cases that consider equality claims, finding discrimination under s. 15(1) where the other seven judges do not.

When one considers that L'Heureux-Dube' and McLachlin JJ. have come to the same conclusion on all three of the trilogy and all the subsequent equality cases, the temptation to place them in the same category is substantial. Nevertheless, McLachlin J.'s application of the analytical framework of s. 15(1) remains closer to that of Sopinka, lacobucci and Cory JJ. than to L'Heureux-Dube' J., even if the results do not.

\section{EXPANDING THE SCOPE OF THE Framework: L'HEUREUX-Dube'}

It is interesting to note that while L'Heureux-Dubé J. arrived at the same conclusion that McLachlin J. did in each case, she did so by expanding the scope of the analytical framework used in Andrews and redefining discrimination. Her approach, explained in Egan, involves expanding the idea of discrimination beyond the enumerated and analogous grounds of s. 15(1) to include individuals that are denied rights because of membership in an identifiable group, which is not necessarily a historically recognized minority. To find that a law violates s. 15(1) under L'Heureux-Dube' J.'s framework, it is necessary to demonstrate the following:

1) there is a legislative distinction;

2) ... this distinction results in a denial of one of the four equality rights on the basis of the rights claimant's membership in an identifiable group;

3) ... this distinction is "discriminatory" within the meaning of $s .15$

[which is proven] ... where it is capable of either promoting or perpetuating the view that the individual adversely affected by this distinction is less capable or less worthy of recognition or value as a human being or as a member of Canadian society, equally deserving of concern, respect, and consideration. (a)

York, supra note 33.

L. Trakman, "Section 15: Equality? Where?" (1995) 6 Constitutional Forum 4.

Egan, supra note 37 at 552-53, L'Heureux-Dubé J. 
Determining discrimination should not be based on relevance to underlying fundamental values but on the reasonableness of the claimant's assertion that they are being discriminated against, as defined above. This conception, a seemingly radical departure when compared with the modified framework of Lamer, La Forest, Gonthier and Major JJ., is concerned with the effect of the laws instead of their purpose and it demonstrates a solid commitment to ideas of substantive equality. Realistically, while L'Heureux-Dube' J.'s commitment to achieving social justice is admirable, it is unlikely to garner much support as it requires a more expansive reading of the Charter than the rest of the Court is prepared for at this point.

Indeed, although L'Heureux-Dubé J. mentions in her concurrence in Vriend the importance of recognizing that discrimination can occur on grounds other than the enumerated or analogous grounds, this position is not reiterated in either Law or $M$. v. $H$; L'Heureux-Dubé J. concurs with the majority judgments of Iacobucci and Cory JJ. in Law and $M$. v. $H$. respectively, which limit s. 15(1)'s application.

\section{Downplaying Difference: The Post Trilogy Decisions}

In the short time since the pronouncement of the equality trilogy judgments in 1995, there have only been eight cases heard by the Supreme Court (all of which are discussed below) that have challenged legislation under s. 15(1) of the Charter. Looking at the judgments as a whole, particularly the last six, it is interesting to note that the Court has sought to downplay the difference between the Gonthier, La Forest, Lamer and Major JJ. position and the McLachlin, Cory, Sopinka and Iacobucci JJ. position. In the equality cases that have come up since the trilogy, Gonthier, La Forest, Major, Lamer, Iacobucci, Sopinka and Cory JJ. have all reached substantially the same conclusion in each case that they sat on with the exception of Gonthier J., who dissented in $M$. v. $H$.

The detailed s. 15(1) analysis that occurs in the trilogy is no longer present except in the dissents of L'Heureux-Dubé and McLachlin JJ. in two of the cases prior to Law. L'Heureux-Dubé J. remained true to her expanded scope framework until Law, finding in each of the last six cases since the trilogy that the Charter applies (even where other judges find that it does not apply due to conflict with the Constitution), ${ }^{61}$ and finding that the discrimination is not justified in all but one case. Similarly, McLachlin J. finds that in each of the six cases that the Charter does apply, and that discrimination is only justified in one case, the same case in which L'Heureux-Dube J. found it justified, albeit for a different reason.

An examination of the post trilogy cases up until Law without the benefit of a detailed analysis of those cases would indicate that seven of the judges have adopted essentially the same framework with a minor variation in their application of the test - the relevance aspect - while one judge, McLachlin J., is somewhat more progressive in her application, and a second judge, L'Heureux-Dubé J. is decidedly 
more so. And this may be correct: by downplaying difference, Gonthier, Major and Lamer JJ. may be signalling that they have rethought their position. On the other hand, they may see the cases as such clearly defined examples of discrimination that a revisitation of the analytical framework is not undertaken simply because it is not required.

\section{A. ADLER V. ONTARIO ${ }^{62}$}

In this case the constitutionality of not funding Jewish and Christian religious private schools in Ontario while funding Roman Catholic religious private school was challenged as being a violation of s. 15(1), discrimination on the basis of religion. The majority found that the funding of Roman Catholic schools was required by s. 93(1) of the Constitution, ${ }^{63}$ and that, since s. 29 of the Charter explicitly exempts from Charter challenge all rights and privileges guaranteed under the Constitution in respect of denominational, separate or dissentient schools, the claimant did not have standing to allege a violation of s. 15(1). Although not considered in the majority judgment, the application of s. 15(1) was considered by two others, McLachlin and L'Heureux-Dube' JJ.

McLachlin J. found that, notwithstanding the constitutionally mandated funding, a system of adverse effect discrimination occurs, but is justified under $\mathbf{s} .1$ by recognizing the government's aim of promoting a multicultural society, which is best encouraged through a public education system. L'Heureux-Dube' J., applying her analysis from Miron, Egan and Thibaudeau, could not find justification for the discrimination under the same grounds as McLachlin J., but she did find "that a denial of health support services for children with disabilities who attend the independent religious schools is impermissible under s. $1 . " 64$

\section{B. COOPER V. CANADA (HUMAN RIGHTS COMMISSION) ${ }^{65}$}

The decision in Cooper did not involve the determination of a s. 15(1) challenge but rather ruled on whether tribunals have the authority to make such determinations in regard to legislation that they are considering. At issue was whether the Canadian Human Rights Commission, or a tribunal appointed by it to investigate a complaint, has power to determine the constitutionality of a provision of their enabling statute. In this case, arising from a challenge to the mandatory retirement age of sixty for airline pilots under the Canadian Human Rights Act, the Canadian Human Rights Commission refused to hear the claimants case on the grounds that the $A c t$ provided for retirement at the industry standard age and the retirement was therefore not discriminatory. The claimants sought review on the grounds that that section of the Act contravened the Charter, and the tribunal was obliged to strike it down. By a majority of five, ${ }^{66}$ the

[1996] 3 S.C.R. 609 [hereinafter Adler].

Supra note 61, s. 93(1).

Adler, supra note 62 at 653 , L'Heureux-Dubé J.

[1996] 3 S.C.R. 854 [hereinafter Cooper].

Major J. and Cory J. did not sit on this case. 
Court ruled that a tribunal appointed at the request of the Commission was without jurisdiction to determine the constitutional validity of a limiting provision of the Act, with L'Heureux-Dube' and McLachlin JJ. dissenting.

While there was no direct ruling on a s. 15(1) issue, it is important to note L'Heureux-Dube' and McLachlin JJ.'s willingness to expand the role of Charter consideration to bodies outside of the courthouse. Their argument is that a failure to do so places an increased burden on the party that is claiming to be the victim of discrimination. The effect of such a limit on administrative tribunals, they argue, is to add another barrier and restrict access to substantive equality. As McLachlin J. states "[t]he Charter is not some holy grail which only judicial initiates of the superior courts may touch. The Charter belongs to the people." ${ }^{67}$

\section{EATON V. BRANT COUNTY BOARD OF EDUCATION ${ }^{88}$}

Unlike the above two cases, this and the following three cases considered the application of s. 15(1) directly. The Court unanimously ruled that it is not a violation of a child's equality rights to place her in special education class to accommodate her disability without her parent's consent. This case is notable for the cursory application of the framework of s. 15(1), relative to that undertaken in Miron, Egan and Thibaudeau, that occurs. The Court considered this to be a clear cut case of nondiscrimination so that neither McLachlin nor L'Heureux-Dub é JJ. felt the need to offer separate judgments applying the s. 15(1) analysis. While the differences between the La Forest and Gonthier JJ. and the Cory and McLachlin JJ. approaches are mentioned, the differences between them are downplayed and, perhaps to avoid addressing them in detail, are summarily applied:

Both Gonthier J. (the Chief Justice and La Forest and Major JJ. concurring) in Miron and La Forest J. (the Chief Justice and Gonthier and Major JJ. concurring) in Egan were of the view that a distinction must be shown to be based on irrelevant personal characteristics. On this view, relevance to the legislative goal or functional value of the legislation where such is not itself discriminatory can negate discrimination. The majority view as expressed in Miron was that relevance may assist as a factor in showing that the case falls into the rare class of case in which a distinction on a prohibited or analogous ground does not constitute discrimination. While this does not purport to be an exhaustive treatment of the differences between the majority and the minority on this point, it is a sufficient synopsis of them for the purposes of this appeal. ${ }^{(1)}$

\section{BENNER V. CANADA (SECRETARY OF STATE) ${ }^{70}$}

The Benner judgment found a violation of s. 15(1) in placing different standards for citizenship on claimants with mothers that were citizens of Canada in comparison with claimants with fathers that were citizens of Canada. This judgment was again a

71 [1997] I S.C.R. 358 [hereinafter Benner]. 
unanimous one. As in Eaton, the Court mentioned the differences between the approaches to s. 15(1) analysis but downplayed their difference and summarily applied the analytical framework:

As I [lacobucci J.] have previously concurred with the test of Cory and McLachlin JJ., my own preference is for their approach, and I apply it in these reasons. However, the result in this appeal is in my opinion the same no matter which test is applied. As I explain further below, the gender of a citizenship applicant's Canadian parent has nothing to do with the values of personal safety, nationbuilding or national security underlying the Citizenship Act. Whether one's mother or father was Canadian is entirely irrelevant to the quality of one's candidacy for Canadian citizenship. Even if relevance is a factor to be considered in weighing legislation in the context of $\mathrm{s} .15$, it is of no help to the respondent in this case."

\section{E. ELDRIDGE v. BRITISH COLUMBIA (ATTORNEY GENERAL) ${ }^{72}$}

Rivalled only by Vriend and $M$. v. $H$. in its significance as a post trilogy equality decision, the Court's decision in Eldridge generated the concern of substantive equality proponents prior to its release. The case challenged the British Columbia Medical Services Commission's failure to exercise its discretion to fund sign language interpreters for hearing impaired individuals receiving health care treatment. Many cited the decision of the British Columbia Court of Appeal that did not find discrimination in this case, ${ }^{73}$ the Supreme Court of Canada's judgments in the equality trilogy, and the Alberta Court of Appeal's decision in Vriend ${ }^{74}$ as evidence of the Canadian judiciary's waning commitment to substantive equality. As in Eaton and Benner, Eldridge was a unanimous decision in which the Court downplayed the differences between the various s. 15(1) analyses. La Forest J., writing for the entire Court, referred to the different analytical frameworks to s. 15(1):

In my view, in the present case the same result is reached regardless of which of these approaches is applied; for similar reasoning, sce Benner v. Canada (Secretary of State), [1997] 1 S. C.R. 358 (per lacobucci J. for the Court). There is no question that the distinction here is based on a personal characteristic that is irrelevant to the functional values underlying the health care system. Those values consist of the promotion of health and the prevention and treatment of illness and disease, and the realization of those values through the vehicle of a publicly funded health care system. There could be no personal characteristic less relevant to these values than an individual's physical disability. ${ }^{75}$

Under the similarly situated approach to testing equality claims, as applied in the B.C.C.A. judgment, those in a similar situation were receiving similar treatment: none of the patients received the benefit of translation. The Court in this judgment, however, provided a more equitable interpretation: those in a similar situation were not receiving

lbid. at 393.

Supra note 21.

Eldridge v. British Columbia (Attorney General) (1995), 7 B.C.L.R. (3d) 156, 125 D.L.R. (4th) 323 (B.C.C.A).

Vriend v. Alberta (A.G.) (1996), 181 A.R. 16, 132 D.L.R. (4th) 595 (Alta. C. A.). Eldridge, supra note 21 at 670 , La Forest J. 
similar benefits as some patients were able to communicate with their doctors, while others, due to physical disability, were not. Again, it is interesting to note how the result may be determined by manipulating the functional underlying values. La Forest J. could have just as easily ruled that the values underlying the health care system were the promotion of health and treatment of illness and disease, realized through the most efficient allocation of scarce monetary resources.

It appears that La Forest J.'s application of the s. 15(1) analytical framework differs from his application in Egan, where he identified the underlying functional values of the specific section of the Old Age Security Act being challenged and not the underlying values of the Act itself. If La Forest J. were following Egan, he should have looked at the underlying functional value of the specific action being challenged, the refusal of the Commission to allocate money to translation services and not the health care scheme itself. In doing so he would have found the functional value behind that decision to be a desire to more efficiently allocate its limited funds to serve a greater number of people.

Reading the Eldridge decision and the additional post trilogy equality cases, it appears that either the minority of the Court that diverged from the Andrews framework in 1995 has reconsidered its approach and is now bringing it into line with the rest of the Court, or that the analytical framework it adopted has been retained, but the process used to define the underlying functional values of legislation is so ambiguous and subjective as to deprive the approach of any consistency. To reach a conclusion, Vriend provides significant insights.

\section{F. VRIEND V. ALBERTA ${ }^{76}$}

The Court, consisting of Lamer C.J. and L'Heureux-Dubé, Sopinka, ${ }^{77}$ Gonthier, Cory, McLachlin, lacobucci, Major and Bastarache JJ. delivered a unanimous judgment that Alberta's IRPA violated the Charter by failing to include sexual orientation in the prohibited grounds of discrimination. While most of the judges agreed that the proper remedy was to read sexual orientation into the entire IRPA, Major J., concurring with the judges on all but the remedy, found that sexual orientation should be read only into the employment provisions of the Act and not the other provisions such as housing and public services. He felt that Charter rights should not be decided in a factual background. L'Heureux-Dube' J. continued her trend of applying an expanded definition of discrimination beyond enumerated or analogous grounds.

The judgment of the Court was delivered jointly by Cory and Iacobucci JJ., the former applying the s. 15(1) analysis and the latter applying the s. 1 analysis to the case. Upon reading the judgment, it is immediately apparent that the Court is continuing the trend evidenced in the three previous cases of downplaying differences between the analytical frameworks. As Cory J. observes: 
In this casc, as in Eaton, Benner and Eldridge, any differences that may exist in the approach to s. 15(1) would not affect the result, and it is therefore not necessary to address those differences. The essential requirements of all these cases will be satisfied by enquiring first, whether there is a distinction which results in the denial of equality before or under the law, or of equal protection or benefit of the law; and second, whether this denial constitutes discrimination on the basis of an enumerated or analogous ground. ${ }^{7 x}$

While Cory J.'s judgment is consistent with the approach that he, McLachlin, Iacobucci and Sopinka JJ. have followed in prior cases, it is important to note that he did not even identify the three step approach of Gonthier and La Forest JJ., making no mention of the relevance of the distinction to the underlying functional values of the impugned sections of the legislation. Although lacobucci J. did not agree with the Gonthier and La Forest JJ. approach, he at least identified the elements of the different approach in Benner. Had another judge addressed the three step approach in this decision, perhaps it might not be significant that Cory J. did not address it. Gonthier J. and Lamer C.J., however, did not offer reasons for judgment and Major J., who had concurred with Gonthier, Lamer, and La Forest JJ. in the trilogy, did not refer to the relevance to functional underlying values analysis under s. 15(1) in his reasons for judgment.

As mentioned earlier in the discussion of the Eldridge case, this approach is inconsistent with that offered in Egan, Miron and Thibaudeau. In those cases, the underlying functional values against which the relevance of the distinction made was measured was not the legislation but the specific section impugned. In Egan, the underlying functional values considered were those that applied to the definition of spouse and not the Old Age Security Act as a whole; in Miron, the underlying functional values considered were those that applied to the section restricting benefits to married couples and not the Insurance Act as a whole; and in Thibaudeau, the underlying functional values considered were those that applied to the section determining which party pays tax on custodial support and not the Income Tax Act as a whole. In Eldridge and Vriend, the reverse is true. In Eldridge the underlying functional values of the Medical Services Act, not those underlying the impugned decision made, were considered; and in Vriend, the underlying functional values of the $I R P A$ are considered, not the values underlying the specific impugned section.

While it can be argued in Eldridge that the underlying functional values of the impugned failure to act and the Medical Services Act are consistent, thus making La Forest J.'s decision in that case consistent with his position in earlier cases, the same cannot be said in Vriend. Cory J. finds the purpose of the IRPA is to protect the inherent dignity and worth of all Albertans and that the Alberta legislature has on numerous occasions refused to add sexual orientation to the prohibited groups of discrimination:

Despite repeated calls for its inclusion sexual orientation has never been included in the list of those groups protected from discrimination. In 1984 and again in 1992, the Alberta Human Rights 
Commission recommended amending the $I R P A$ to include sexual orientation as a prohibited ground of discrimination. In an attempt to effect such an amendment, the opposition introduced several bills; however, none went beyond first reading. Although at least one Minister responsible for the administration of the IRPA supported the amendment, the correspondence with a number of cabinet members and members of the Legislature makes it clear that the omission of sexual orientation from the IRPA was deliberate and not the result of an oversight."

Cory J.'sjudgment indicates that the functional values underlying the IRPA and those underlying the specific sections that exclude sexual orientation from the $A c t$ are not the same. Since sexual orientation was specifically and deliberately excluded from the $I R P A$, it follows that the distinction made by doing so is relevant to the underlying functional values of that exclusion, if not to the legislation as a whole. The Gonthier and La Forest JJ. three step approach as applied in the trilogy should have found a distinction but then found that it was not discriminatory as it was relevant to the underlying functional values of the impugned section, unless of course the purpose of the legislation was invidious.

The Respondents did not submit evidence as to the purpose of the exclusion of sexual orientation from the IRPA is, either in their factum or in their oral arguments, possibly because they realized that the reason for the exclusion itself was not based on a valid purpose but was discriminatory. As Major J. noted:

The Province of Alberta was invited to but declined at the appeal to explain how people with different sexual orientation were not part of the phrase "all persons are equal in dignity and rights." As well, the Province of Alberta failed to demonstrate how the exclusion of sexual orientation from the IRPA accords with its legislative purpose. It is puzzling that the Legislature, having enacted comprehensive human rights legislation that applies to everyone in the province, would then selectively deny the protection of the Act to certain groups of individuals."

Major J. made the above statement in the context of a s. 1 analysis and not a s. 15(1) analysis. Having been a supporter of the original La Forest and Gonthier JJ. relevance formulation in the trilogy cases, it is interesting to note that he now considers relevance in the context of a s. 1 analysis as per the original Andrews approach and not in s. 15(1). This indicates that Major J. at least has either abandoned or rethought the three step approach.

\section{ReAfFirming the ANDREWS COMMITMENT}

Prior to the Vriend decision it appeared that either the minority of the Court that diverged from the Andrews framework in 1995 has reconsidered its approach and is now bringing it into line with the rest of the Court, or that the analytical framework adopted is retained, but the process used to define the underlying functional values of legislation is so ambiguous and subjective as to deprive the approach of any 
consistency. After the decision in Vriend was released, it seems that the former is true for the following reasons:

1. There is a consistent downplaying of "differences that may exist in the approach to s. 15(1)" that is part of a pattern in recent equality cases;

2. The "difference" referred to is neither addressed nor applied by any judge in the most recent cases;

3. All of the judges in the four cases prior to Law have ruled unanimously that a Charter violation existed, despite worries that these would be "hard" cases;

4. Although the underlying functional values of the impugned sections are clearly different from those of the relevant legislation in Vriend and Eldridge there is no application of the relevance test; and, most significantly,

5. One of the judges subscribing to the minority's three step framework, Major J., has implicitly rejected that framework by testing relevance in $\mathrm{s} .1$ instead of $15(1)$.

While it is impossible to know why Lamer, Major and Gonthier JJ. have re-evaluated their three step approach, it does appear that they have either implicitly, though not explicitly, abandoned it in favour of the Andrews approach or have decided that a purposive approach should be greatly broadened. Whichever the case, it appears that the similarly situated test or reasonable classification approach that their relevance test had approximated has been rejected, quite possibly because of the criticism levelled against it both from within and outside the Court. Perhaps Gonthier and La Forest JJ. did not realize the significance of their modified framework, that it could easily be construed as an application of the similarly situated test under a different name. It seems that McIntyre J.'s wish that the similarly situated test be abandoned may now, some ten years later, be fulfilled.

\section{A. LAW V. CANADA ${ }^{81}$}

After Vriend and Eldridge, the Court's necessity to restate its analytical framework used to evaluate s. 15(1) was apparent. The Court received this opportunity in Law v. Canada and delivered a succinct, unanimous judgment writing through laccobucci $J$. The Court stressed that s. 15(1) analysis was to be purposive and contextual. As in previous decisions, the Court ignored the differences in approaches from the equality trilogy of 1995 and instead restated general principles evident in earlier jurisprudence. Law introduces an analytical framework which adopts the two-step approach of Andrews and incorporates a new third step rooted in the purpose of s. 15(1): 
1. Does the impugned law impose differential treatment between the claimant and others by drawing a formal distinction or failing to take into account the claimant's disadvantaged position in society?

2. Is this treatment based on an enumerated or analogous ground?

3. Does the differential treatment disadvantage the claimant in a manner which reflects the stereotypical application of presumed group characteristics or promote the view that the claimant is less worthy of equal recognition or respect as a human being or member of society? ? $^{82}$

In order to determine the third step, the Court must evaluate the impugned law by considering the context of its application from the perception of the claimant. The Court lists four key areas that should be considered under this third step:

a) Pre-existing disadvantage, stereotyping or vulnerability to the claimant,

b) Correspondence between the claim and the actual need or circumstances of the claimant,

c) The ameliorative purpose or effect of the impugned law on other groups in society, and

d) The nature and scope of the interest of the law.

The newly modified framework is significant because it restricts the instances in which a law may be found discriminatory. The framework effectively limits the application of s. 1. If an impugned law operates in accordance with the above contextual factors - recognizing pre-existing disadvantage, corresponding with the claimant's need, furthering or not infringing an ameliorative purpose, and affecting an important interest - it will likely meet the Oakes test under s. 1 and be upheld.

In applying the new analytical framework to the facts of the case, the Court found that while there was a distinction drawn on an enumerated ground - a denial of spousal survivor benefits to Law based on her age - this did not constitute discrimination under s. 15(1). Under the third step, there was no conflict with the purpose of s. 15(1), to ensure and promote the human dignity of all members of society. Applying the four contextual factors to the denial of benefits to those under thirty, the Court found that "the differential treatment does not reflect or promote the notion that they are less capable or less deserving of concern, respect, and consideration, when the dual perspectives of long-term security and the greater advantage of youth are considered." ${ }^{83}$ Since there was no violation of s. 15(1) it was unnecessary for the Court to consider the application of $\mathrm{s} .1$. 
Taken by itself, Law would suggest that the Court has firmly re-established its stance of ten years previous and has fully returned to the ideals of substantive equality as articulated in Andrews. The Court did, however, apply the new Law framework less than two months later in the case of $M$. v. $H$. and, as Cory and Gonthier JJ.'s judgments demonstrate, an approach to s. 15(1) entirely consistent with substantive equality has not been achieved.

\section{B. $M$. v. $H^{84}$}

The Court's almost unanimous decision in $M$. v. $H$. was a revisitation and reversal of the decision in Egan which had found the definition of spouse restricted to opposite sex couples was not discriminatory. The majority, applying the Law contextual factors to the Family Law Act, found the following: a) the Act impacted a group, gays and lesbians, that was subject to pre-existing disadvantage and stereotyping; b) it failed to address the claimant's actual situation by implying that same-sex relationships were impermanent or non-conjugal; c) the claimants were excluded from the ameliorative purpose of the $A c t$; and d) the economic and social nature of the interest was important. ${ }^{85}$ In meeting all four contextual factors, in addition to the first two steps of distinction and enumerated grounds, the majority found the law violated the purpose of s. 15(1). Finding a violation of s. 15(1), the majority then proceeded to find a violation of s. 1, recognizing that, while access to spousal support was pressing and substantial, excluding same-sex couples from support was not rationally connected to the goal of providing support, significantly impaired the rights of others and was not proportional.

In contrast, Gonthier J. found no s. 15(1) violation, based on the advantaged position of individuals in same-sex relationships relative to women in heterosexual relationships: "the evidence indicates that lesbian relationships are characterized by a more even distribution of labour, a rejection of stereotypical gender roles, and a lower degree of financial interdependence than is prevalent in opposite-sex relationships." ${ }^{186}$ Applying the Law contextual factors, Gonthier J. found that: a) while lesbians and gays were historically disadvantaged, they were not disadvantaged in the subject matter of the legislation; b) the legislation took into account the needs of same-sex couples; c) same-sex couples were excluded, but not disadvantaged by exclusion, from the ameliorative purposes of the $A c t$; and d) denying same-sex individuals access to support did not deny an important interest. Having found no violation of s. 15(1), Gonthier J. did not address s. 1.

It is apparent from the differing results that the application of the Law contextual factors is subjective. The reason for the difference is the focus placed on the purpose of the impugned legislation. Cory J. writing for the majority on the s. 15(1) analysis, finds the purpose of s. 29 of the Family Law Act to be "providing for the equitable

$M$. v. H., supra note 2 , paras. $68-72$.

Lamer, L'Heureux-Dube, McLachlin and Binnic JJ. writing through Cory and lacobuci JJ., Major J. concurring, Bastarache J. concurring, and Gonthier J. dissenting.

Supra note 84, para. 242. 
resolution of economic disputes when intimate relationships between financially interdependent individuals break down" ${ }^{87}$ without regard to the gender of the partners. Gonthier J., in contrast, finds "that the purpose of the spousal support provisions of the $F L A$ is to remedy the systemic sexual inequality associated with opposite-sex relationships." ${ }^{18}$ Bastarache J., in separate reasons concurring with Cory J., agreed with Gonthier J.'s understanding of the $F L A$ 's purpose, to address inequality in heterosexual relationships. Bastarache J. did not, however, agree with Gonthier J.'s finding that the purpose of excluding same-sex couples was to recognize the relative advantage that those in same-sex relationships experience over women in heterosexual relationships. ${ }^{89}$

$M$. v. $H$. is an important development in the s. $15(1)$ analytical framework because of the focus that Cory and Gonthier JJ. place on the purpose of the impugned legislation. The results that they achieve are dependent upon their respective interpretations of the reasons for the impugned law. Cory J.'s analysis focused on the purpose of the spousal support provisions while Gonthier J.'s focused on the purpose of the exclusion from access to spousal support provision. Cory J. credited the legislature with a broader purpose than Gonthier or Bastarache JJ. found and downplayed the actual wording of the statute, which has a more restrictive effect than the purpose he interpreted it to have.

Interestingly, Gonthier J. found the purpose of excluding same-sex couples was to recognize their relative advantageous position and not to reflect perceived societal moral values about homosexuality. Gonthier J.'s purpose was not arrived at based on the recognition of functional underlying values. The exclusion of same-sex couples based on moral reasons is a possible purpose of the legislature, but Gonthier J.'s failure to address this issue, which also occurred in Egan, indicates the abandonment of the explicit functional underlying values analysis. Instead, discussions of the possible moral values underlying legislation may become obscured in future judgments. For whatever reason, the Court appears reluctant to admit that the purpose for a law or policy may be rooted in social or moral values that are prejudicial unless that purpose is clearly invidious, as in Vriend. A failure to discuss the true purposes of legislation in the $s$. 15(1) analysis may prevent a full discussion of the justification of the legislation under the $s .1$ analysis. For example, by failing to address reluctance to recognize gay and lesbian relationships as a purpose of the definition of spouse in the $F L A$, the Court is not obliged to decide whether that is a valid legislative purpose under $\mathrm{s}$. 1. While this is convenient for the Court, and still consistent with the end of substantive equality, improperly classifying the purpose of legislation to avoid discussing the validly of making decisions based on moral values is ultimately a disservice to society.

The Law approach, as applied by Cory and Gonthier JJ., is highly subjective and may lead to the overemphasis, or even invention, of a particular purpose of the legislation, while downplaying or ignoring the true purpose intended by the legislature,

k7 Ibid., para. 106.

*A Ibid., para. 202.

8I) See supra note 86 and accompanying text. 
based on a desire to achieve a specific result in the case and to avoid inevitable social debate and criticism of the Court. Compared with Cory and Gonthier JJ.'s judgments, Bastarache J.'s decision in $M$. v. $H$. is the approach most consistent with the principles of substantive equality. Bastarache J. recognized the same purpose as Gonthier J. for the extension of the spousal support provisions, but sees no valid purpose for the exclusion of gays and lesbians. Bastarache J.'s approach places a greater emphasis on the effects of the $F L A$ than does Gonthier or Cory JJ.'s.

Law stresses the need for purposive and contextual analysis, and the Court must ensure that it recognizes that evaluating the effects of legislation may often be more important than classifying the purpose. Although the Court has renewed its commitment to the goals of substantive equality with Law, this latest modification of the s. 15(1) analytical framework may prove to be too subjective. As $M$. v. $H$. demonstrates, the focus on purpose instead of effect demonstrated by Gonthier and Cory JJ. puts the Court in the difficult position of divining legislative intent to justify the purpose of the legislation. How the Law contextual approach will develop obviously remains to be seen. While Law stands as a significant step on the path to substantive equality, the Court, as $M$. v. $H$. demonstrates, is not completely there yet. 